\title{
Teaching Practice in Distance Education Context
}

\author{
Rhini Fatmasari and Suripto \\ Faculty Education of Indonesian Open University (UT)
}

\begin{abstract}
Teaching practice is an activity designed to enable students in mastering teaching skills. This activity is very important to improve the ability of prospective teachers, because theoretical knowledge has not been able to equip the teaching practice. The practice of teaching at schools provides a real experience for students in the real class, because theoretical knowledge through the process of learning in the classroom can not equip the teaching practice.

Faculty of Teacher Training and Education of Indonesia Open University (UT) with distance learning system has designed Teaching Practice through Praktek Kemampuan Mengajar (PKM) course with 3 credit score. PKM is implemented in the schools where they teach and are guided by two supervisors. The PKM exam is conducted at the designated centre schools at each UT Regional Office .

This study is aimed to evaluate the activities of PKM students of Economic Education Studies Program FKIP UT in UT Regional Office. The study was conducted at 12 UT Regional Office samples involving respondents consisting of UT students and UT Regional Office staff.

The results showed the level of independence of students doing PKM was quite high (72\%). This level of independence needs to be supported by a $43 \%$ improvement in preparation and administrative services at UT Regional Office. In the implementation of teaching practice in schools, in average $53.14 \%$ Supervisor 1 and $63.86 \%$ Supervisor 2 always provide direction in accordance with UT standards. While $62.5 \%$ of Headmaster Sentra has role in accordance with its function.
\end{abstract}

Key word: teaching practice, UT, UT Regional Office

\section{Background}

The teaching capability is main requirement teacher must have in their professionalism. Since teaching is not only routine and mechanical activities, but needs a series of skills that teacher must possess. In teaching activities consist of capabilities to analyse students' needs, decision making what should be done, planning the effective and efficient learning, activating students through both extrinsic and intrinsic motivation, evaluating the learning result, also revising the next learning to be more effective and to increase students learning achievement. Therefore teaching is a managerial activity that must be implemented professionally.

Theoretically, Professionalism capabilities can be obtained by prospective teacher through learning process in a lecture. But these capabilities were not enough to equip for doing teaching learning process in the class. So, a briefing of gradually designed teaching practice, is needed by students to master teaching skills. 
Universitas Terbuka as long distance university owned 279.873 (70,50\%) students of FKIP that it's graduations would have professions as a teacher. One of the subjects to be taken by students in finishing their study at FKIP UT is Praktek Kegiatan Mengajar (PKM) subject. PKM is a program to train students as a teacher in managing learning to be effective and efficient. PKM essentially trains and equips students with organizing capabilities (preparation, planning, implementing, evaluating and improving) learning at middle schools (Junior and Senior High school or others in the same level) based on learning principles that can be accounted for by the truth. PKM implementation is an activity of teaching practice done by students of FKIP UT at Centre determined by a local UT Regional Office . Through strengthening teaching capabilities (PKM), a teacher is expected to be able to increase educational qualification and professional capabilities of the teacher.

Based on the importance analysis of PKM for the students prospective teachers and research results in the field, UT needs to make an evaluation on the effectiveness of PKM implementation, especially for Student non basic education. This evaluation is addressed to UPBJJ as administrator of learning in general, Students Study Group as PKM Organizers, and school where practice activities take place. The evaluation is done to see (1) PKM's Plan and Administration at UPBJJ, and (2) recruitment system of PKM potential participants, system of RP development guidance and PKM practice and also teaching training system and teaching practical exams at Study Group (Kelompok Belajar).

\section{LITERATURE REVIEW}

\subsection{Teaching Practice}

Planned, directed and sustained educational reforms can be implemented and running well if teachers are able to increase and develop their qualities and qualifications. Those improved qualities and qualifications are expected to be able to increase the teacher professional capabilities in order to produce a better generation in the future days. Teaching is an activity that aims to create a possible condition that students can study. According to Oemar Hamalik (2001), teaching had several important definition: a) deliver knowledge to the students in schools; b) passed a culture down to young generation through school educational institution; c) the effort to organize environment to create learning condition for students; d) gave learning guidance to students; e) prepared students to be a good citizen accordance to society demands; f) a process to help students in facing daily life of society. While Sardiman (2004) explained that teaching was an activity that organized or managed the environment well and connected to a child, so learning process was happened. It could be said that teaching was an effort to create conducive situation to the ongoing learning activities for students. This condition was created in a way to support children development optimally both physically and spiritually, also both physically and mentally. Dadang Suhardan (2006) state that teaching was an academic activities consisting of communication interaction between educator and students.

\subsection{Practice of Teaching Ability}

Students of S1 FKIP UT are teachers who implement learning activities, were considered important to stabilize their teaching skills (PKM). Through PKM teachers were trained and equipped with habits to prepare, plan, implement, evaluate and improve learning at schools based on teacher's knowledge and education that can be truly responsibled.

Stabilization of teacher abilities (PKM) is a program to train student as a teacher in managing effective and efficient learning. At the end of stabilization of teaching abilities 
(PKM), students are required to make PKM report. PKM reports is made as one of requirement to take exams of Stabilization of teaching abilities subject (PKM) PDGK 4209 Program S1 PGSD FKIP Universitas Terbuka.

\subsection{Implementation of Teaching Practice at Universitas Terbuka}

a. Exercises/practices of teaching, Students who implement exercises/practices of teaching, must create : (1) 10 sets of Learning Implementation Plan (RPP) and it's teaching practice in school where they work; (2) 8 RPP + their practices were assessed by supervisor 2 with using observation sheet.

b. Assessment of exercises include 1 RPP + its practice which was assessed by supervisor 2 and available teacher's colleague at school and 1 RPP - its practice was assessed by supervisor 1 and their college students in the tutorial class.

c. PKM report component includes Introduction, Findings of learning, conclusion, also its attachment which consist of 8 RPP, 8 observation sheets, 8 forms of reflection sheet.

d. The exams of teaching practice, (a) consist of 2 RPP and 2 teaching practice; (b) the exams of teaching practice is conducted at school determined by UPBJJ as PKM center; (c) The examiner recaps the scores by using Form PKM PGSM 2; (d) exams score contributes $40 \%$ towards final scores of PKM course/subject.

e. Pattern of PKM tutorial; (a) activities of PKM tutorial includes guidance and independence activities; (b) guidance by Supervisor 1 is implemented as much as 8 meeting times; (c) one class of PKM tutorial consist of 15 students.

\section{METHODOLOGY}

\subsection{Design, Population and Research Sample}

This research is a monitoring and evaluation that used design of evaluative description through a survey, observation and interviews. Population in this research were students who took PKM course/subject and UPBJJ that conducted PKM. UPBJJ sample was taken by using purposive sampling with considering the total students implementing the practice at the UPBJJ. The instrument developed in this research were questionnaires form and interviews guidance. Data of this questionnaires would be analysed descriptively by using the middle value trend and percentage. At the same time, data got from interviews would be analysed by content analysis.

\section{ANALYSIS AND DISCUSSION}

\subsection{Respondent}

Respondent in this research were students of S1 Economics Education, Head of UT Regional Office and Academic Coordinator in UT Regional Office. Total respondents and distribution of students per UPBJJ can be seen in Figure 1 as follows :

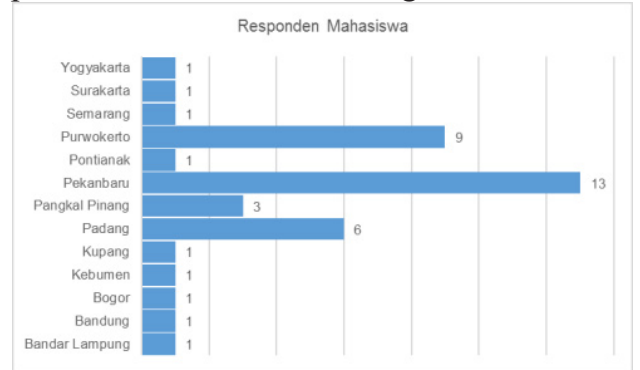

Figure 1 Total and distribution of students per UT Regional Office 


\subsection{Discussion of Research Result}

Questions asked to students were related to (a) students independency in taking PKM course/subject, (b) tutorial by supervisor 1; and (c) Co tutorial by Supervisor 2. The indicators of PKM Practice and result of questionnaire processing on the whole can be seen in Table 1 and Figure 3 as follows:

Table 1. Indicators of PKM Practice

\begin{tabular}{|c|c|}
\hline NO & Category \\
\hline \multicolumn{2}{|r|}{ Students' independence in taking PKM/course/subject } \\
\hline 1 & Students registered by him/herself to take PKM course/subject \\
\hline 2 & Students could decide what the best time they must take PKM course/subjects. \\
\hline 3 & Students made 10 sets of Plan of Learning Implementation 9RPP) and teaching practice at school where students taught. \\
\hline \multicolumn{2}{|r|}{ Tutorial/gudance of Supervisor 1} \\
\hline 4 & Students got tutorial by Supervisor 1 at PKM Centre determined by UT Regional Office \\
\hline 5 & Tutorial by Supervisor 1 implemented in 8 times meeting, located in tutorial class determined by local UPBJJ. \\
\hline 6 & Supervisor 1 appointed had the same background of knowledge with the students \\
\hline 7 & Supervisor 1 appointed could guide students well \\
\hline 8 & Supervisor 1 guide, discuss and give inputs of RPP and PKM report made by students \\
\hline 9 & Supervisor 1 discussed and gave inputs to learning implementation done by students \\
\hline 10 & Supervisor 1 guided students in fill their own reflection sheet. \\
\hline 11 & $\begin{array}{l}\text { Supervisor } 1 \text { guided and evaluated PKM reports which were written by students based on evaluation guidance which was } \\
\text { avaliable in PKM Guidance Modul }\end{array}$ \\
\hline 12 & Recommendation of exams to students provided by Supevisor 1 \\
\hline 13 & Recommendation of exams to students provided by Supevisor 1 \\
\hline \multicolumn{2}{|r|}{ Tutorial Supervisor 2} \\
\hline 14 & Students chose Supervisor 2 and teacher who were in the same school \\
\hline 15 & Students chose Supervisor 2 from teacher who were in the same school \\
\hline 16 & Supervisor 2 guided, discussed and gave inputs to students in making RPP \\
\hline 17 & Supervisor 2 evaluated RPP using observation sheet \\
\hline 18 & Supervisor 2 evaluated RPP using observation sheet \\
\hline 19 & Based on observation result, Supervisor 2 gave inputs to students about RPP and teaching practice that have been done \\
\hline 20 & Based on observation result, Supervisor 2 gave inputs to students about RPP and teaching practice that had been done \\
\hline 21 & $\begin{array}{l}\text { Supervisor } 2 \text { filled journal of guidance appropriate with journal of PKM activities that had been done under guidance } \\
\text { Supervisor 2, known by Supervisor } 1\end{array}$ \\
\hline 22 & Tutorial by Supervisor 2 was done in 8 times \\
\hline 23 & Supervisor 2 guided students in teaching practice in their own class by using observation sheet, then discussed the result \\
\hline 24 & $\begin{array}{l}\text { Supervisor } 2 \text { filled journal of guidance which was signed by Supervisor } 2 \text { and students and submitted to Supervisor } 1 \text { and } \\
\text { UPBJJ }\end{array}$ \\
\hline 25 & Supervisor 2 evaluated students in Teaching Practice 1 time by using APKG PKM 1 and 1 \\
\hline 26 & Supervisor 2 appointed having the same field of science with the students \\
\hline
\end{tabular}

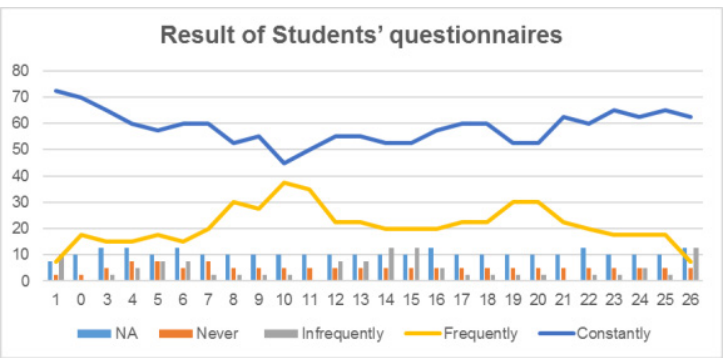

Figure 2. Result of Student Questioners

Figure 2 showed that UT students were very independent in taking PKM Course /Subject. Students could determine accurately when they must take PKM course/subject and made their own Learning Plan. Beside that, on the side of Supervisor 1, students got well enough guidance. Practice that must get attention from UPBJJ and UT was an existences of PKM Centre and the background of Supervisor 1 that was not similar with the guided students. This happened if UPBJJ did not have Supervisor 1 who had similar educational background appropriated with the determined requirements. This condition was also happened if at 
UPBJJ whose the total students took PKM course/subject did not reach 1 PKM tutorial class (10 persons)

Questionnaire results also showed that UPBJJ must increase roles of Supervisor 1 in guiding students, especially in filling self reflection sheet and made PKP report. This was happened since students took PKM at every UT Regional Office that spread throughout the region. Supervisor 1 and Coordinator of UT Regional Office explained that it was very difficult to gather students regularly every weeks.

Problems in managing PKM in long-distance educational context especially for FKIP regular students were how to control the involvement of Supervisor 2 actively. Result of the research at Figure 4 showed that $47,5 \%$ Supervisor were not always giving inputs to students about RPP and teaching practice that had been done. While 42,5\% Supervisor 2 were not always guiding and giving inputs to students in making Learning Improvement Plan. Managing PKM at UPBJJ showed that there were some activities that needed improvement and special attention. Result of questionnaire process about managing PKM at UPBJJ can be seen at Figure 3 and Tabel 2 as follows :

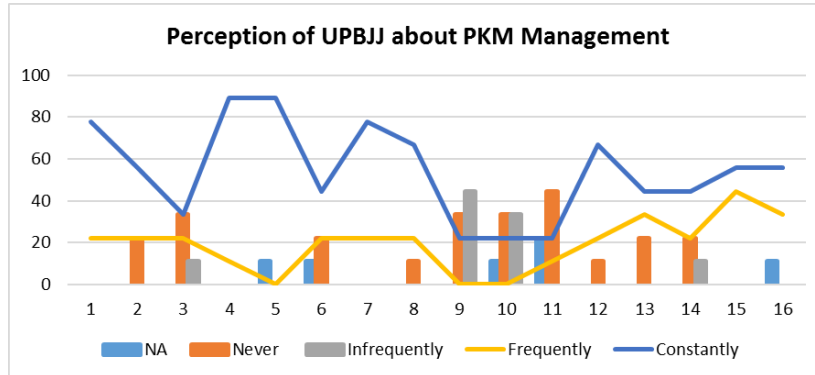

Figure 3. Perseption of UPBJJ

Table 2. Indicators of PKM Management in UPBJJ

\begin{tabular}{|c|l|}
\hline No & \\
\hline & Plan and PKM administration at UPBJJ \\
\hline 1 & UT Regional Office prepared students data of prospective PKM participants based on Registation Data \\
\hline 2 & UT Regional Office decided location of PKM Guidance \\
\hline 3 & Name of Supervisor 1, Supervisor 2< Examiner and PKM Evaluator were prepared by UT Regional Office \\
\hline 4 & Selection of Supervisor 1 refered to Procedure of Selection and Evaluation of academic staff Non- UT \\
\hline 5 & UPBJJ adjusted the competency of Supervisor 1, Supervisor 2, Examiner and PKM Evaluator \\
\hline 6 & $\begin{array}{l}\text { UPBJJ implemented orientation of PKM tutorial implementation, by inviting prospective supervisor 1 and Study Group } \\
\text { (Pokjar) Organizer }\end{array}$ \\
\hline 7 & UPBJJ/UT prepared Practice Material, Report Forms and Recapitulation format of PKM practice assessment. \\
\hline 8 & $\begin{array}{l}\text { UPBJJ submitted technical guidance of PKM tutorial and file completeness of PKM guidance (included APKG, PKM 1, } \\
\text { APKG PKM 2, Tutorial Journal, APL, PKM PGSM to supervisor 1 and supervisor 2 via students. }\end{array}$ \\
\hline 9 & UPBJJ did monitoring of PKM guidance implementation PGSM peridically. \\
\hline 10 & Monitoring was done in 3 times \\
\hline 11 & UPBJJ prepared PKM centre, location of teacing practice examination \\
\hline 12 & UPBJJ received PKM final score/assessment and submitted to UT exam center. \\
\hline 13 & Location of PKM practice exam decided by UT Regional Office accordance to Prodi requirement. \\
\hline 14 & UPBJJ evaluated Supervisor 1 through questionnaire \\
\hline 15 & UT Regional Office ensured the guidance took place accordance to schedule and conditions. \\
\hline 16 & UPBJJ identified if some problem deviation happened in implementing PKM \\
\hline
\end{tabular}

Figure 3 showed PKM organizeer/management at UT Regional Office that needed attention such as : (1) Preparation name of Supervisor 1, Supervisor 2, Examiner and PKM evaluator by UT Regional Office . Implementation in the field up to this day, Supervisor 1, Supervisor 2, examiner and PKM evaluator were prepared by study group. While 
Supervisor 2 searched by students was their own senior teacher at their school. The problems happened were the educational background Supervisor 2 that was not similar with the students who took PKM subject; (2) UPBJJ conducted orientation of PKM tutorial implementation by inviting prospective supervisor 1 and study group (pokjar) management. This activity was rather difficult implemented by UPBJJ since the spread of students and prospective supervisor was uneven. At some UPBJJ that had students domiciled in the island region where this activity was difficult to be implemented.

Only 22,2\% UPBJJ sample that did monitoring the PKM implementation, 33,3\% did not do this activity regularly. Interview results with UPBJJ staff explained that monitoring activities did not implement accordingly, since UT policy determined that only $30 \%$ tutorial location which were monitored every semester. Therefore not all PKM practice activities in every location could be monitored by UPBJJ staffs. Supervision of PKM implementation by students was monitored by Supervisor 2, supervisor 1 and Study Group Management (4) Monitoring was done in 3 times. By the similar reason with monitoring activities, so UPBJJ could not do PKM monitoring in 3 times. 33,3\% UPBJJ never did 3 times monitoring directly (5) UPBJJ prepared PKM Centre where the location of teaching practice exam was.

Preparation of PKM Center and location of teaching practice exam were indirectly handled by UPBJJ. This activity was handled by Group Study (pokjar) organizer. 44,4\% UPBJJ did not handle the organizer which related with practice location and PKM exams. Organizer of study group usually establish cooperation with schools located around the tutorial location to serve as a partners in conducting the teaching practice exams. Meanwhile activity of teaching practice during 8 weeks done by students at school where they work. (6) Location of PKM practice determined by UT Regional Office was appropriated with determined Prodi. Determination of teaching practice exams was implementation by $44,4 \%$ UPBJJ, $22,2 \%$ UPBJJ could not determine that appropriate with Prodi requirement. This determintation was very dependent on condition in every region. In some regions even it was very difficult to be done, since there was no school that met the determined criteria, UPBJJ provided policy to implement PKM practice exam at school available in those region; and (7) UPBJJ evaluated Supervisor 1 through questionnaire. Evaluation activity of Supervisor 1 through questionnaire only implemented at 44,4\% UPBJJ, while 22,2\% other UPBJJ did not ever do evaluation through questionnaire. Interview Result with staff UPBJJ explained that they did evaluation of Supervisor 1 through study group organizer. This evaluation was felt more optimally since directly done in the field

Activities of other PKM organizer/management by UPBJJ were considered good enough and have met the requirement determined by ISO UT related to PKM management of non Basic Education. Although there were not $100 \%$ activities done by UT Regional Office .

\section{CONCLUSION}

Based on result of research about implementation of Teaching abilities Practice of students S1 UT economic Education could be concluded that : (1) UT needs to increase monitoring toward implementation of Teaching Practice in the field, especially related to management by UPBJJ. There were still 5 activities which its implementation level in the field were very low; (2) the involvement Study Program in overseeing the teaching practice activities are needed, therefore one mechanism need to be made in order Study Program could directly involve in management and PKM practice. 


\section{References}

1. A.M, Sardiman, Interaksi Dan Motivasi Belajar Mengajar, Jakarta: Rajawali Pers (2004)

2. Dadang Suhardan, Pengawasan Profesional, Bandung: Dewa Rhuci (2006).

3. Hamalik, Oemar, Proses Belajar Mengajar, Jakarta : Bumi Aksara (2001).

4. Irna Fitriana, Yudha Prasetyawan, ST, M.Eng Analisis Dampak Rencana Pembangunan Busway terhadap Kemacetan Lalu Lintas pada Jalur Utara - Selatan Dengan Pendekatan Sistem Dinamik. , digilib.its.ac.id/.../ITS-Undergraduate-11032-Paper.pd.

5. Pemantapan Kemampuan Mengajar (PKM) PDGK 4209 program S1 PGSD FKIP Universitas terbuka.

6. Wahyuni Kadarko, Pelaksanaan Praktek Mengajar Bagi Guru Peserta Pendidikan Jarak Jauh Yang Tinggal Di Wilayah Terpencil, Jurnal Pendidikan, Volume 11, Nomor 2, September 2010, 78-87.

7. Standar JKOP BB07 tentang Prosedur Penyelenggaraan Bimbingan Praktik PKM Dan PKP Program Pendas dan Nonpendas FKIP

8. Undang-Undang No. 20 Tahun 2003 Tentang Sistem Pendidikan Nasional 